\title{
Language and Politicking: A Pragmatic Analysis of Political Texts in Political Posters and Jingles in Oyo State, Nigeria \\ By
}

\author{
Ajayi, Temitope Michael \\ Department of Linguistics and African Languages, \\ University of Ibadan, Nigeria \\ michealtemitope@yahoo.com/ajayi.temitope@dlc.ui.edu.ng \\ and \\ Ajayi, Daniel Oluwafemi \\ Department of English Studies \\ Adekunle Ajasin University, Akungba Akoko, Ondo State, Nigeria \\ ajayidanielo84@gmail.com
}

\begin{abstract}
This paper attempts a pragmatic analysis of political texts in political posters and jingle(s) of gubernatorial candidates for 2015 General Elections in Oyo state, Nigeria, within the purview of Mey's (2001) Pragmatic Acts Theory. Data was collected from political posters and jingles of Governor Abiola Ajimobi(the incumbent governor of the state), the erstwhile governors of the state, Rasheed Ladoja and Alao Akala, and Professor Adejumo, a yet to be declared PDP's gubernatorial candidate for the said election. The study reveals that the language of politicians in the state is characterised by practs such as accusation, challenge, abuse, warning, persuasion, commendation and condemnation which draw on contextual features such as Shared Situational Knowledge (SSK), Shared Cultural Knowledge (SCK), Metaphor (MPH) and Relevance (REF).
\end{abstract}

The paper concludes that politicians in the state, an indication of what happens on a large scale in the country, employ language to attack one another's personalities, rather than address issues that could help move the state forward.

Keywords: Political Texts; Gubernatorial Candidates; Oyo State; Elections; Nigeria.

\section{Council for Innovative Research}

Peer Review Research Publishing System

Journal: Journal of Advances in Linguistics

Vol 3, No. 3

editor@cirworld.com

www.cirjal.com, www.cirworld.com 


\section{Introduction}

Language is a social tool that is essential to every walk and domain of life, politics inclusive. As such, politicians often employ this social tool to woo the hearts of the electorate, and most times run down and berate their opponents; even without expressly mentioning names. Such is the case in Oyo state of Nigeria, where political rivalry has manifested in the creative and captivating ways political parties and electoral candidates deploy language to sell their ideologies to the electorate, as well as castigate their opponents. Of particular note in this regard is the rivalry that ensues among the three dominant political parties in the state, namely APC, PDP and AP.

\section{Background Knowledge on the Rivalry among the Political Parties and Governorship Candidates in Oyo State}

With the rebirth of democracy in Nigeria in 1999, virtually all the Southwestern states in the country, including Oyo, were won by $A D$, with PDP controlling the central seat of power. However, the temptation to feel the federal power came in 2003 when all the AD controlled states clamoured the PDP governance. Sequel to this, all the states previously controlled by $A D$, except Lagos were taken over by PDP. It was during this period that Chief Rasheed Adewolu Ladoja emerged the governor of the state on the platform of the PDP, with Akala occupying the office of the Deputy Governor. In the middle of the administration however, Ladoja obviously fell out of favour with some powers that be in the state, and was evetually impeached. His impeachment then paved the way for Akala to take over the mantle of leadership in the state; a development which many, including Ladoja himself, considered to be an act of betrayal, hence the following enmity and rivalry between the two. The matter resulted in a judicial battle that lasted for months, but all to no avail for the ousted governor.

Governor Abiola Ajimobi came to the scene in 2003 when he contested against Akala and Ladoja (PDP candidates) on the platform of ANPP. Following the declaration of Akala as the winner of the election, there was a protracted period of litigation by Ajimobi to seek redress. However, the judgement of both the Tribunal and Appeal courts went in favour of Akala. Then in 2011, the trio of Akala, Ladoja and Ajimobi recontested for the same governorship position, but this time, it was in favour of Ajimobi. However, from all indications, it appears the three have not relented yet in their bid to occupy the seat in 2015, hence their political postals and wordfare on the streets of Oyo state.

\section{Language and Politics}

If one can imagine how important water is to fish, one can then appreciate the relationship between language and politics. The two concepts are so interconnected that the latter cannot survive without the former. Language is said to be the vehicular expression of politics; the means by which politics or political discourse and ideas are widely disseminated (Ayeomoni, 2004). In line with this position of the quoted scholar, Mazrui (1995) opines as follows:

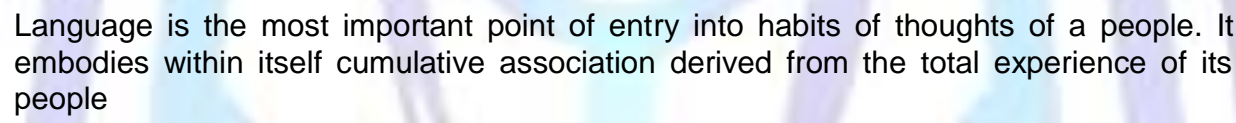
people

( Mazrui, (1995) in Ayeomoni (2004))

Also, Harris (1979) states that words have a powerful effect in politics. To this effect, he quoted George Orwell as saying " political language is designed to make lies sound truthful and murder respectable". He went further to conclude that language is the means by which political ideas are transmitted to the community. In this regard, Ranney (1975) cited in Ayeomoni (2004) submits:

Every political authority will lead to justify itself by an appeal to language in its symbolic or realistic sense.

Deduceable form all the views of these scholars is the fact that politics rides on the shoulder of language; it is the backbone of politics. As a matter of fact, politics would not have a place in any society without language. Politicians use language to campaign, persuade, accuse, convey their ideologies, as well as play on the minds of the electorate.

\section{Theoretical Issues}

This work is carried out within the theoretical framework of Pragmatic Acts, as proposed by Mey (2001) and contextually modified by Odebunmi $(2006,2008)$. According to these scholars, pragmatic act is exigent in view of the limitations of the speech act theory popularly employed for pragmatic analysis. In particular, (Mey 2001), speech act theory is non-situated. And considering the data gathered for analysis in this work, the theory is considered relevant. Mey (2001) explains the concept of a pragmeme with the model below: 
Figure 1:

\section{ACTIVITY PART}

(INTERACTANTS)

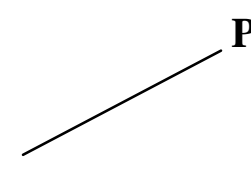

PRAGMEME

INF REF REL VCE SSK MPH “M” .....

\section{TEXTUAL PART}

$(\mathrm{CO}(\mathrm{N}) \mathrm{TEXT})$

SPEECH ACTS

INDIRECT SPEECH ACTS

CONVERSATIONAL (DIALOGUE) ACTS

PSYCHOLOGICAL ACTS (EMOTIONS)

PROSODY (INTONATION, STRESS,....)

PHYSICAL ACTS:

BODY MOVES (INCL. GESTURES)

PHYSIOGNOMY (FACIAL EXPRESSIONS)

(BODILY EXPRESSIONS OF) EMOTIONS
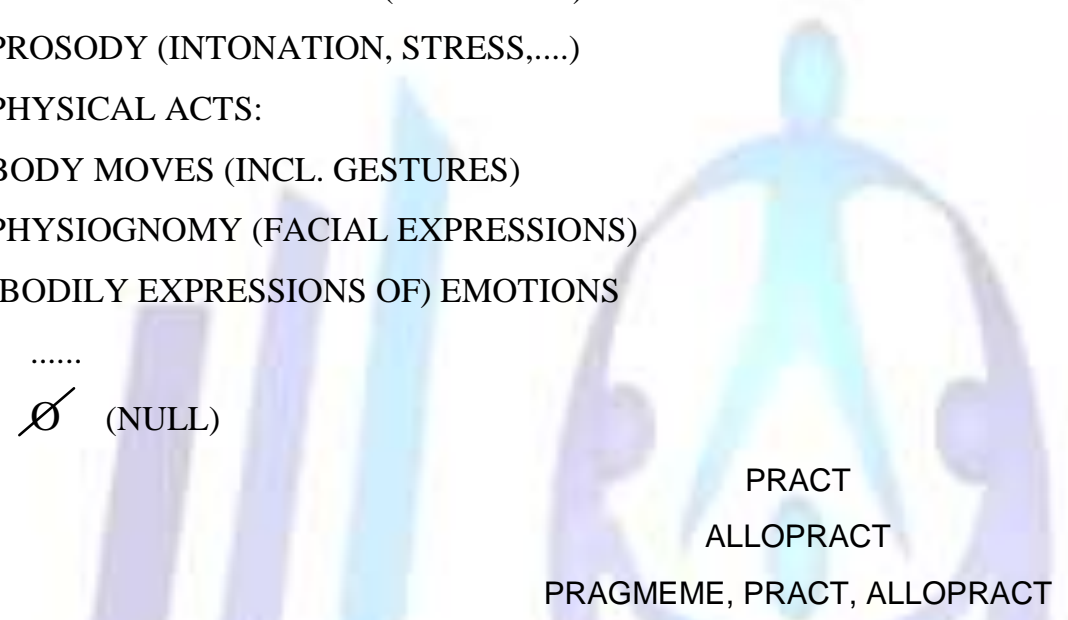

In the words of Mey (2001: 221), the pragmatic act theory focuses on "the environment in which both speaker and hearer find their affordances, such that the entire situation is brought to bear on what can be said in the situation, as well as what is actually being said". This view is captured as a pragmeme, a generalized pragmatic act regarded as the only force associated with making utterances (Odebunmi, 2008: 76). A pragmatic act is instantiated through an ipra or a pract, which realizes a pragmeme. "Every pract is at the same time an allopract, that is to say a concrete instantiation of a particular pragmeme" (Mey 2001: 221). What determines a pract is solely participants' knowledge of interactional situation and the potential effect of a pract in a particular context.

Thus, practing resolves the problem of telling illocutionary force from perlocutionary force (Odebunmi, 2008). In the above scheme, the column to the left itemises the various choices that the [S]peaker and $[\mathrm{H}]$ earer have at their disposal while speaking. The S may choose one of the several of these available options; if all the cells are empty, the matrix goes to zero, indicating the borderline case of silence (Mey, 2001). The column to the left shows the textual part, that is, the context within which the pragmeme operates). For meaningful communication, the interactants rely on such speech act types as indirect speech acts, conversational ('dialogue') acts, psychological acts, prosodic acts and physical acts. These are engaged in contexts, which include INF representing "inference"; REF, "relevance"; VCE, "voice"; SSK, "shared situation knowledge"; MPH, "metaphor"; and M "metapragramatic joker". Thus, the interaction between activity part and textual part results in a pract or an allopract. However, Odebunmi (2006) introduces SCK (shared cultural knowledge) to be able to adequately account for the cultural factor in the use of proverbs, as used in "The gods are not to blame" as follows:

\section{Proverbs}

S

$\mathrm{H}$

CMP NMP

Social Political

Psychological acts

context

REF, MPH

INF, SSK, SCK 
REL

Practs:

counselling, cautioning

accusing, challenging,

veiling, persuading, prioritizing,

encouraging, admitting, threatening

Figure 2: A modified Model of Pragmatic Acts in The Gods are not to Blame

Source: Odebunmi (2008)

Adopting the model above, this present work is analysed with the schema below:

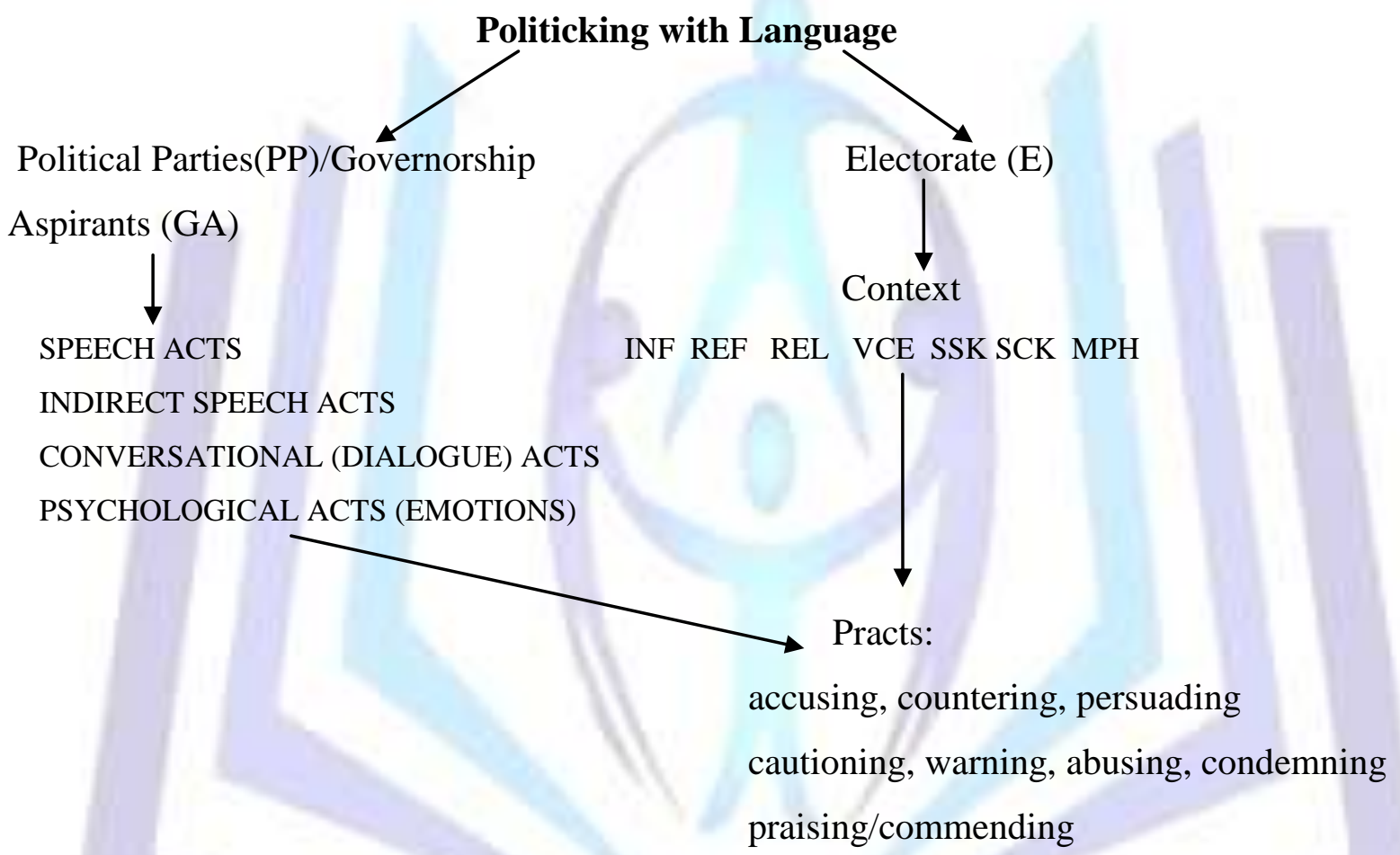

\section{Data Presentation and Analysis}

Datum 1: Alao Akala's Postal

Ajjùmọbí ò kan tàánú, ẹni t'ólúwa bá rán síni níi ṣeni lóore

" the fact that you are related to an individual by blood does not mean such an individual could be beneficial to you; it is he who God has sent to you that can actually help you"

This is a Yoruba ideological statement that empasizes their cultural beliefs in the concept of destiny and God, being the almighty, determines what happens to one. The erstwhile Governor Alao Akala resorts to the use of this statement to cast aspersion on the administration of the incumbent governor, Ajimobi, who is equally planning to run for the gubernatorial seat for the second time. Here, Akala makes use of contextual features such as SSK, SCK and REL to achieve his goal. $\mathrm{He}$ is actually referring to the political situation of the state under the administration of Ajimobi, where quite a number of people are complaining bitterly about the many reformative policies of the governor. For instance, the governor embarked upon mass demolition of 'unapproved' warehouses, shops and buildings, especially in Ibadan (the capital city of the state) as soon as he assumed office; a development many have claimed has brought untold hardship to them and their family at large. By the statement above, Akala means to assert that the fact that Ajimobi hails from Ibadan has not prevented him from being malicious and inhumane, even to his own people. 
Akala believes the interpretation of his ideological statement by the electorate will rely heavily on the Yoruba cultural belief that not even your own family members could be of help to you, except Elédùmarè "God" has predestined it. This is against the backdrop that the votes of the people of lbadan go a long way in determining who emerges as governor of the state, and Ajimobi, being an Ibadan man, easily rode to power on this "Ibadan sentiment" . It must also be pointed out here that the use of this ideological statement by Akala is intentional, as it contains the word "Ajumobi" which is used in this context to indirectly refer to 'Ajimobi', the name of the incubent governor. This is done to create a special effect. From the foregoing therefore, Akala accuses Ajimobi of being mean to the people of the state, especially the lbadan people, and warns them against trusting him with their votes in the 2015 elections. How do we know that the use contextual features : SSK, SCK and REL help Akala in driving home his point? The answer is not far fetched as there was a quick response from the other quarters barely a week after Akala put up his postals. This is captured in the data below.

Datum 2: Ajimobi

In a postal that carried the distorted pictures of Akala and Ladoja, Ajimobi (or perhaps his supporters) replied as follows:

\section{"2 wrongs can never make a right"}

In this advertorial, Ajimobi fights back drawing on contextual features such SSK, MPH and REL. To start with, the response of Ajimobi or his supporters is relevant to the initial comments made by Akala in his ideological statement. Also, drawing on the Shared Situational Knowledge (SSK) of what transpired between Akala and Ladoja when the duo paddled the canoe of the state between 2003 and 2007 and the rivalry that had started between him(Ajimobi) and Akala since 2007, Ajimobi hopes to discredit the candidature of the two with his response. During this period, there was a protracted conflict of interest between Akala and Ladoja, especially as the latter was thrown out office and the former "enthroned" as governor, when he was supposed to be deputizing the former, and Akala being declared the winner of the election conducted in 2007 at the expense of Ajimobi, amidst controversies though. To Ajimobi, if the antecedents of these two, Akala and Ladoja, as painted above, is anything to go by, then they are not fit to run the affairs of the state again. Their combination would rather constitute a clog in the wheel of the progress of the state instead of moving it forward. This he expects the electorate to decode by metaphorically referring to the duo as "two wrongs". The pract here is that of subtle warning and persuasion to the peolple of the state not to make the mistake of giving their votes to Akala and Ladoja the second time. In a dramatic response and reaction, Akala and Ladoja (or perhaps their supporters) submit as follows:

Datum 3: Akala and Ladoja (with their beautiful pictures and Ajimobi's distorted picture)

\section{"Two good heads are better than one"}

Drawing on contextual features of SSK, REL and MPH, the duo of Akala and Ajimobi speak with a common voice that they are the best candidates for the governorship seat, come 2015. They make a metaphoric reference to themselves as being "good heads" which are unequivocally better than Ajimobi in terms of administration. Their comment has relevance to the conversational exchange that has been initiated by Akala in his first postal. Shared Situational Knowledge comes to play when their response is viewed in the light of the purported complaints and agonising comments of the people of the state under the administration of Ajimobi, compared to a "relatively peaceful and serene atmosphere" that characterised their own administarion. With this comment, Akala and Ladoja counter the argument of Ajimobi that they are wrong choices for the seat.

Datum 4 PDP : Professor Adejumo

The People's Democratic Party's candidate joined the conversation along the line with the comments below:

\section{Come with me to liberate Oyo state from oppression and heavy yoke and together we will restore hope, progress accountability and transparent leadership}

Here, Adejumo projects himself as the Messiah the people of the state need to liberate them from the "era of oppression they have been subjected to" by the present administration. The oppression described here is such that can be understood and appreciated via share situational knowledge (SSK). To him, it is common knowledge that repression and oppression hold sway in the administration of Ajimobi, especially as the governor has embarked on policies that aggravate the pitiable condition of the people of the state. He further makes recourse to the use of shared cultural knowledge (SCK) of the people of the state, who are largely Yoruba, to persuade them to vote for him. This is because he knows the people of the state, who are largely Yoruba, believe in the spirit of unity and oneness in achieving common goals, as captured in this statement in the language of the people: Àgbájọọ́ lafi ń sọyá, àjèjì ôwó kan ò gbệrù dórí which implies it is difficult for a people to achieve a common goal without unity. He uses the pronoun "we" to show solidarity and oneness with the people (electorate).

Datum 5: A radio Jingle sponsored by Wasiu Adewale Olatunbosun

İjẹta r'ápe șùgbọn kò rínádá; àná dáná șùgbọ́n kò r'ápẹ gbéle. Òní r'ígi tò sáàrò a dúpẹ ó r'íná dá ó sì tún r'ápe gbéle . Ișu ègbodò ni gbogbo wa fi l'anú ìjoba àwarawa. A túșu sódó, òní gúnyán ìyán òhún kò sì lẹmọ́ . B'ọbẹ iṣápá ${ }^{1}$ ti ń sọ láàrò n'ìjoba ne t'ẹní òri'; ó ní óyá ká máa jẹn lọ. Bàbá àgbà ló pè wá s'àkíyèsí pé ìjẹta tí ò ríná dá, àt'àná tí ò r'ápe gbé léná ni wộn mà ne kó kùmọ bọ yù̆, wộn fệ ba àsè yíi jệ. Ó

\footnotetext{
${ }^{1}$ A kind of soup of the Yoruba people, usually reputed to be the best of all their soups, especially when eaten along with pounded yam

${ }^{2} \mathrm{~A}$ traditional mat usually used for relaxation in Yoruba
} 


\author{
d’ọwọ gbogbo wa ni ò ; ẹẹ ká mọ iyì òní tóbá dàmọdún ká lè jọ wá jó gbànkẹtẹ ， \\ t’oróun òní șe fún wa ló fi wá lọkàn balẹ pé ọla wa yóò dara.
}

The day before yesterday secured a cooking pot but found it difficult to prepare a meal. Yesterday set the fireplace but could not secure a cooking pot to place on it. Today has sufficient firewood to keep the fireplace burning and able to secure a cooking pot set on the fireplace. We have been able to harvest fresh yam in this democratic setting. With the yam harvested, today has prepared very smooth and succulent pounded yam. As the Isapa soup is gathering heat on the fireplace, the government is preparing a big mat to be sat upon to have the meal. The old man has then called our attention to the fact that both yesterday and the day before, who could not achieve the feat today has recorded, are approaching with sticks in their hands to disrupt our meal. It is left to us. Let us appreciate today; then by next year, we can come rejoicing, for what today has done for us has assured us of a beautiful tomorrow.

\title{
Source: Oluyole fm (96.5), Ibadan, Oyo State
}

In the excerpt above, the speaker makes extensive reference to items found in the socio-cultural setting of the Yoruba people, to which the people of Ibadan in particular, and Oyo state in general belong. Some of these items are ape "cooking pot", ààrò "fireplace", Ișu ègbodò "fresh yam", odó "mortal(pestle)", iyán "pounded yam", etc. The interpretation of these items as used in this political jingle is assisted by SCK, the speaker being a Yoruba man and the audience, largely being Yoruba. SSK helps us in appreciating the message in the advert better. Going by the political antecedents of the trio of Ladoja, Akala and Ajimobi and all that has transpired among them in the last nine years, it then suffice to say that the day before yesterday in the text metaphorically (MPH) refers to Ladoja, who was not able to complete his tenure, having been ousted in the middle of his tenure as governor of Oyo state, hence "İjẹta r'ápe sùgbọ́n kò rínádá" "The day before yesterday secured a cooking pot but found it difficult to prepare a meal". To the speaker, Ladoja could not really achieve anything while being governor of the state. In the same vein, yesterday in the text refers to Akala, the immediate past governor of the state. He too is regarded as an half achiever as far as his administration of the state is concerned-àná dáná șùgbọ́n kò r'ápe gbéle 'Yesterday prepared the fireplace but could not secure a cooking pot to place on it". However, today refers to Ajimobi, the incumbent governor of the state. As far as the speaker is concerned, Ajimobi is an achiever, who has recorded immesurable achievments in all ramifications as governor. He has succeeded in ameliorating the suffering of the people, by empowering them with what would constantly put food on their table.

Also, reference to bàbá àgbà (line 5-7) "old man" in the text is a reference to the shared cultural knowledge of the Yoruba people that elders are endowed with "inner eyes" to see far ahead into the future. In the Yoruba socio-cultural setting, elders are blessed with wisdom, intuition, instinct and wit to foresee what the young ones cannot see, and that is why they are often revered and highly respected by the young ones. Similarly, the speaker employs SCK, calling on all and sundry to collectively work together to protect the present administration. This call is anchored on the speaker's awareness of the collective spirit of the Yoruba people to achieve a common goal, as explained earlier. In this text therefore, the speaker accuses the past two administrations of being failures, condemns their disruptive and destructive tendencies and commends or praises the present administration for doing wonderfully well. He also persuades the people, electorate to continue supporting the present administration, especially as she is preparing for the next year's(2015) elections.

\section{Conclusion}

So far, it has been made apparent in this paper that language is a mjor tool or weapon politicians employing in politicking. In their political campaigns, especially in their advertorials, they employ language to accuse, challenge, abuse their opponets. In the same vein, politicians employ language to create good impression in the mind of the electorate about themselves, and warn or caution the electorate not to go for any other candidate, as this would be tantamount to making the wrong choice. What then becomes obvious in the above-painted scenario is the fact that politics of bitterness and character assasination is still in vogue in Nigeria, even after fifteen years of democracy. Politicians attack personalities instead of addressing issues that border on ameliorating the suffering of the people and move the state forward.

\section{References}

Ayeomoni, M.O. (2004): A linguistic-stylistic investigation of the language of of the Nigerian elite. In Oyeleye, L. (ed.) Language and discourse in society. Hope Publications Ltd, Ibadan

Harris, P.B. (1979): Foundations of political science. Methourine Sidney: Auckland, Joannesburg.

Inya, O. (2012): Defending a Thesis: Pragmatic Acts in Contemporary Christian Apologetics, Theory and Practice in Language Studies, Vol. 2, No. 10, pp. 2016-2023, accessed 20/02/2014

Mey, J. (2001): Pragmatics. An Introduction. Oxford.

Odebunmi, A. (2008). Pragmatic Functions of Crisis - Motivated Proverbs in Ola Rotimi's The Gods Are Not to Blame. Linguistik online 33/1 accessed 20/02/2014

Odebunmi, Akin (2006): "A Pragmatic Reading of Yerima's Proverbs in 'Yemoja Attahiru' and 'Dry Leaves on Ukan Trees'". Intercultural Pragmatics 3, 2: 153-170. 


\section{Sources of Data}

Alao Akala's Poster, January 2014.

Alao Akala and Rasheed Ladoja's Poster, January 2014.

Abiola Ajimobi, Alao Akala and Rasheed Ladoja's Poster, January, 2014.

Professor Adejumo's Poster, January, 2014.

Oluyole fm (96.5), Ibadan, Oyo State. Radio Jingle, recorded 04-03-2014, 6:45 a.m. 